\begin{tabular}{|l|l|}
\hline Postprint Version & 1.0 \\
\hline Journal website & $\underline{\text { http://dx.doi.org/10.1016/j.ejca.2008.12.011 }}$ \\
\hline Pubmed link & $\underline{\text { http://www.ncbi.nlm.nih.gov/pubmed/19167212 }}$ \\
\hline DOI & $10.1016 /$ j.ejca.2008.12.011 \\
\hline
\end{tabular}

This is a NIVEL certified Post Print, more info at http://www.nivel.eu

\title{
Towards more patient centred healthcare: a new Consumer Quality Index instrument to assess patients' experiences with breast care
}

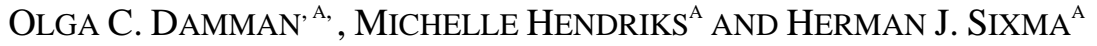

${ }^{a}$ NIVEL (Netherlands Institute for Health Services Research), Department of Demand-Driven Healthcare, P.O. Box 1568, 3500 BN, Utrecht, The Netherlands

\begin{abstract}
Objective: To develop a Consumer Quality Index (CQ-index) Breast Care instrument that measures quality of care from the perspective of patients with (suspicion of) breast cancer.

Methods: To develop a pilot questionnaire, three focus group discussions with breast cancer patients were performed. The questionnaire was sent to 1197 patients. We performed psychometric and descriptive analyses to optimise the new instrument.

Results: Focus group discussions revealed nine main themes related to breast care quality. Psychometric analyses resulted in 15 reliable scales. The final instrument consisted of 152 items, of which 118 items regarded patients' experiences. The aspect with the highest need for quality improvement was informing patients about a second opinion.

Conclusion: The CQ-index Breast Care (CQI-BC) instrument provides a good starting point for further research on the quality of breast care seen from the perspective of patients. The newly developed instrument can be used by different stakeholders for future quality monitoring.
\end{abstract}

\section{INTRODUCTION}

Healthcare systems in many countries are moving towards more patient centred care. In this process, transparency about healthcare quality is an issue of paramount importance. In addition to the release of clinical outcome data, which usually originate from medical professional groups, effort has been made to assemble and report patients' own quality assessments. Patient and public involvement in defining and assessing healthcare quality has now been introduced in various countries. ${ }^{[1],[2]}$ and [3]

In the Netherlands, the assessment of patient experiences in healthcare is standardised using Consumer Quality Index (CQ-index or CQI) surveys. ${ }^{[4] \text { and [5] }}$ The CQ-index is based on two families of instruments: (a) American CAHPS (Consumer Assessment of Healthcare Providers and Systems) ${ }^{6}$ and (b) Dutch QUOTE (QUality Of Care Through the patient's Eyes) instruments. ${ }^{1}$ The strengths of both methods have been combined: the frequency with which quality criteria are met (CAHPS) and the importance of quality aspects (QUOTE) are 
Damman, O.C., Hendriks, M., Sixma, H.J. Towards more patient centred healthcare: a new Consumer Quality Index instrument to assess patients' experiences with breast care. European Journal of Cancer: 2009, 45(9), 1569-1577

integrated in patient surveys. A four-point answering structure of experience items ('never', 'sometimes', 'usually', 'always'), and a four-point scale of importance items ('not important', 'fairly important', 'important', 'extremely important') are the questionnaires' basis. In addition, global ratings of healthcare and healthcare professionals as well as items on problems concerning accessibility of care are standard elements.

Like CAHPS and QUOTE, CQI instruments assess patients' experiences, rather than their satisfaction. Experience measures are known to be less subjective and to yield more detailed information for quality improvement than satisfaction measures. ${ }^{7}$ An advantage of standardised instruments is that healthcare performance can be compared over years ${ }^{8}$ and across healthcare sectors. Importantly, CQI information can fulfil different stakeholders' information needs: (a) consumers on the healthcare market and health insurance market, who are more and more expected to act as informed and critical decision makers; (b) healthcare providers monitoring their provided healthcare; (c) health insurance companies on the health purchaser market; (d) patient organisations which represent patients' interests and needs; (e) healthcare inspectorates supervising healthcare quality; and (f) governments monitoring general healthcare quality. Using the CQ-index is thus efficient; several parties, having their own needs, are provided with quality information through one single measurement. At present, a large amount of CQI information is assembled, using general, ${ }^{9}$ sector-specific ${ }^{10}$ and disease-specific ${ }^{[4]}$ and $[5]$ questionnaires. Particularly, disease-specific instruments are expected to play a major role for healthcare providers because these instruments provide detailed information about particular patient groups within specific healthcare settings. In addition, from the patient's perspective, disease-specific quality aspects contribute to the (face) validity of the instruments.

Within the set of disease-specific CQI questionnaires, a breast care instrument was developed from December 2006 to October 2007: the CQI-BC. Since breast cancer generally brings about many emotional and psychosocial consequences, ${ }^{[11], ~[12], ~[13] ~ a n d ~[14] ~}$ and breast cancer care is rather complex and prolonged, it seems obvious that patients will search for a high quality treatment in a high quality hospital. Therefore, an important aim of the instrument is to develop public comparative information for future patients. Besides patients, medical care providers or professionals are important potential users of the instrument, since comparative information can enforce quality improvement initiatives through both internal and public hospital reports. ${ }^{15}$ Insight into patient's experience allows professionals to compare the quality of care they provide with that of their colleagues in other hospitals, and might be a stimulus to improve public perception of their own hospital.

Our aim was to develop a CQI-BC instrument that is both scientifically grounded and manageable by several users. In this article, we describe the development of the CQI-BC, while focusing on the application of the instrument by one important group of potential users, namely, healthcare providers and professionals. In this context, aspects of care that need quality improvement were explored, and options to report CQI information are discussed.

\section{PATIENTS AND METHOdS}

The construction of the new survey was based on CQI protocols. ${ }^{16}$ The CQI-BC was developed in close cooperation with key stakeholders (representatives of health insurance companies, a patient organisation, the Dutch Institute for Healthcare Improvement, a surgeon, a radiologist, a radiotherapist, a nurse practitioner and an oncologic psychologist) to ensure public support.

\subsection{Construction pilot questionnaire}

To construct the pilot version of the CQI-BC instrument, we performed three focus group discussions with breast cancer patients in February and March 2007. Participants were recruited through (a) a purposive sample of 100 breast cancer patients of a health insurance company; (b) patient organisations' advertisements; and (c) advertisements in two hospitals. 
Damman, O.C., Hendriks, M., Sixma, H.J. Towards more patient centred healthcare: a new Consumer Quality Index instrument to assess patients' experiences with breast care. European Journal of Cancer: 2009, 45(9), 1569-1577

We initiated the discussions using open-ended questions, ${ }^{17}$ such as 'Describe some positive and negative experiences that you have had with breast care' and 'According to you, what makes good quality breast care?' Two researchers acted as moderators in the discussions, structuring the discussion, asking for elaborations and encouraging participation. Discussions were audio-taped with participants' permission, and transcriptions were analysed by two researchers independently. We used descriptive thematic analysis, focusing on quality aspects relevant for participants. In addition to the focus group results, existing Dutch questionnaires on breast care (see, for example, de Kok et al. ${ }^{18}$ ) and key stakeholders' input were used to construct the questionnaire. The stakeholders wanted the questionnaire to cover care for both patients with malignant and benign breast disorder, since breast care in the period of breast examinations and diagnostics should be adequate for both groups.

\subsection{Data collection}

In May 2007, the pilot version CQI-BC Experience (containing questions on patients' experiences) along with a pilot version CQI-BC Importance (containing questions on the importance patients attach to quality aspects) was sent to a stratified sample of 1197 patients. These individuals were selected from claims data of four health insurance companies. Inclusion criteria were (1) being older than 18 years; (2) having received breast care in the last 24 months; and (3) not being approached in the past for CQI surveys. Half of the patients had malignant breast disorder and half had benign breast disorder. Persons having malignant breast disorder had to fill in the complete questionnaire, whereas persons with benign breast disorder were instructed to skip items on breast cancer treatment. We sent all patients a mailing with the request to fill out the questionnaire, and a 'thank you card' was sent 1 week later. A second questionnaire and letter in the fifth week, and a reminder letter in the seventh week were sent to non-respondents. $1^{9}$

\subsection{Analyses}

Analyses were performed in July and August 2007.

\subsubsection{Psychometric properties}

We performed psychometric analyses to assess (a) appropriateness of items; (b) dimensional structure of the questionnaire; (c) reliability of scales; and (d) importance of quality aspects. To create a manageable instrument, we aimed to abbreviate it to a survey containing only the most relevant and reliable items. Items selected for elimination were (1) extremely skewed items ( $>90 \%$ of answers in extreme category); (2) items with a high nonresponse ( $>5 \%$ missing values); (3) items with low importance scores; (4) one of the two items having a strong mutual relation (Pearson's correlation $r>0.70$ ); (5) items not fitting into scales (factor loading $<0.40$ in explorative factor analyses); and (6) items not contributing to scale reliability (Cronbach's alpha $<0.70$; Item-total correlation $<0.40$ ). However, policy considerations of stakeholders to maintain items were also considered. After a final discussion among stakeholders, the revised CQI-BC instrument was constructed.

\subsubsection{Quality improvement scores}

To identify the aspects of quality of care that are particularly eligible for improvement, we conducted descriptive analyses. First, the proportions respondents reporting negative experiences on the different items were assessed. Second, we calculated the average importance scores on all items, which could vary from 1 ('not important') to 4 ('extremely important'). These two types of scores were then combined in a so called quality improvement score, using the formula: proportion negative experience * importance score. The higher the score, the more reason there is for improvement. 
Damman, O.C., Hendriks, M., Sixma, H.J. Towards more patient centred healthcare: a new Consumer Quality Index instrument to assess patients' experiences with breast care. European Journal of Cancer: 2009, 45(9), 1569-1577

\section{RESULTS}

\subsection{Focus groups}

A total of 27 breast cancer patients participated in the focus group discussions ( $n=11$, $n=9$ and $n=7)$. Participants' mean age was $51(\mathrm{SD}=11.5$; minimum $=26$; maximum $=73$ ). Data analyses resulted in nine main themes related to breast care quality. These themes concerned general aspects, such as conduct of healthcare professionals, as well as more disease-specific aspects, such as options for an immediate breast conserving treatment and referrals to follow-up care. The nine main themes were (1) conduct of healthcare professionals; (2) time schedule; (3) information services; (4) accessibility of care; (5) expertise of healthcare professionals; (6) continuity of care; (7) autonomy; (8) hospital facilities; and (9) psychosocial care and aftercare.

\subsection{Pilot questionnaire}

The pilot questionnaire CQI-BC Experience consisted of 166 items, of which 114 items regarded actual patient experiences. The remaining items were skip-items (items screening eligibility of respondents to answer specific items and instructing to skip corresponding items), items on questionnaire improvement and items on person characteristics. The questionnaire was divided in eleven sections: (1) introduction (6 items); (2) breast examinations (28 items); (3) breast surgery (43 items); (4) other treatment (35 items); (5) after treatment (12 items); (6) cooperation and continuity (7 items); (7) accessibility (11 items); (8) expertise (2 items); (9) global rating hospital (3 items); (10) improving the questionnaire (3 items); and (11) about the respondent (16 items). The content of questionnaire items is described in Table 1.

\section{[TABLE 1.]}

Content of experience items (abbreviated) in the CQ-index Breast Care Experience survey, with a specification of the type of item and the translation into importance items.

The pilot questionnaire CQI-BC Importance consisted of 68 items. In principle, we asked for all aspects how important respondents found them. Quality aspects represented more than once in the CQI-BC Experience questionnaire, such as conduct of professionals (general practitioner, surgeon and nurses), were converted into one importance question.

\subsection{Response}

A total of 731 patients (63\%) filled in the experience survey. The importance instrument was completed by 706 persons (60\%). Of all 731 respondents, 38\% had benign breast disorder, 57\% had breast cancer and 5\% had breast carcinoma in situ. Two respondents were male, and the age distribution was as follows: $4 \%$ of the respondents were younger than 35 , 14\% were aged between 35 and 44, 25\% were aged between 45 and 54, 30\% were aged between 55 and 64 and 27\% were aged between 55 and 64 years.

\subsection{Psychometric results}

Forty-three items had a missing value rate of more than 5\%, 15 items were extremely skewed and 5 items showed an importance score of lower than 3 . From factor and reliability analyses, it appeared that the experience questionnaire could be structured into fifteen reliable scales which represent breast care quality aspects. These scales, covering 59 items, are displayed in Table 2. Cronbach's alpha varied from 0.68 to 0.93 .

\subsection{Adjustment of the instrument}

In total, 31 items were considered for removal from the questionnaire. These items did not fit into one of the scales, were absent in the top ten of highest importance scores and did not comply with one or more of the item analysis criteria (distribution of answers, missing value rate, mutual relation). After a discussion with key stakeholders, we eliminated 16 of the 31 selected items. A substantial number of items have thus been retained based on policy arguments. An example is the item 'Was the medical surgery coordinated by a specialised 
Damman, O.C., Hendriks, M., Sixma, H.J. Towards more patient centred healthcare: a new Consumer Quality Index instrument to assess patients' experiences with breast care. European Journal of Cancer: 2009, 45(9), 1569-1577

nurse?' Although the item did not fit into a scale, was not considered extremely important, and was skewed, stakeholders suggested that performance on this aspect is likely to differ across hospitals, and that the item should therefore remain in the CQI-BC. Furthermore, eight items were rephrased, rather than eliminated. The revised version of the experience instrument contained 152 items, of which 118 items concerned patients' experiences.

\subsection{Quality improvement scores}

Table 3 shows the ten quality aspects that are most eligible for improvement of breast care, according to patients. Importance scores as well as the proportions respondents reporting negative experiences with healthcare are presented for these aspects. The aspect 'information about a second opinion' appeared to be the aspect that needs improvement most, followed by 'consult radiotherapist preceding medical surgery'. Concerning the three quality aspects that were applicable to both patients with benign and patients with malignant breast disease, patients with benign breast disease reported more negative experiences.

Fig. 1 graphically displays improvement potential on a selection of items from the questionnaire, by comparing patients' experiences on the $y$-axis to the importance they attach to different aspects on the $x$-axis. As can be seen, it is easily noticed to which aspects priority for improvement initiatives should be given, namely, to information on a second opinion and to rapid hospital appointments after a referral. These aspects of care are the aspects that patients find important, and on which negative experiences are reported.

Fig. 1. Example of quality information for healthcare providers: quadrant figure presenting quality improvement potential*. *Rule of thumb for importance score: all aspects with an importance score of 3.00 and higher are considered important; Rule of thumb for experience score: all aspects with proportion negative experiences of 0.15 or higher are considered negative experiences. Aspects in the upper right quadrant are aspects that need improvement with priority (action). Aspects in the upper left quadrant are aspects that need improvement without priority (no action). Aspects in the lower right quadrant are plus points (keep up the work). Aspects in the lower left quadrant are relatively unimportant aspects.

\section{[TABLE 2]}

\section{DISCUSSION}

Our aim was to develop a CQI-BC instrument with good psychometric properties as well as with the capacity to be used by several stakeholders in the healthcare market. Several quality aspects important to patients were reliably measured. While we removed several items from the questionnaire, a substantial number of stable quality aspects remained in the instrument on which future information can be created. In short, the CQI-BC forms a good basis to investigate breast care quality from the patient's perspective, and can be used for future quality monitoring by different users.

It is important that CQI information is clearly presented to healthcare providers, to stimulate their use of the information when initiating quality improvement efforts. Quality improvement scores are one way for hospitals or individual professionals to get informed about their performance. Providers can prioritise which aspects to pay attention to: to aspects with negative experience and high importance, and then to aspects with average experience and high importance and so on. In this study, information about a second opinion appeared to be particularly eligible for quality improvement.

Besides quality improvement scores, various other report options are available to inform providers about patients' experiences and priorities. We gave an example of a graphical display of improvement potential, by comparing patients' experiences to the importance they attach to aspects of care. Another common method is to present patients' experiences using horizontal bar graphs. Such bar graphs are usually presented on item level, so that aspects requiring extra consideration can be comprehensively identified. As appears from these 
Damman, O.C., Hendriks, M., Sixma, H.J. Towards more patient centred healthcare: a new Consumer Quality Index instrument to assess patients' experiences with breast care. European Journal of Cancer: 2009, 45(9), 1569-1577

examples, aspects of care needing consideration can be easily detected using the instrument. Further research is needed to assess how healthcare professionals would like to be provided with CQI information.

\section{[TABLE 3]}

\section{[FIGURE 1]}

In the context of information based on patients' own quality assessment, important strengths of the CQI methodology are the role of focus group discussions, as well as quantitatively testing how important patients find different quality aspects. These two methods are crucial to ensure that the patient's perspective is incorporated into surveys, and will contribute to the instrument's (face) validity. However, external validation testing and more extensive reliability testing (e.g. test-retest reliability) are needed to further establish the value of the instrument in the healthcare market.

The main purpose of research using the CQI Breast Care instrument is to routinely assess quality of care from the patient's perspective in different hospitals. However, CQI data could be used for a variety of other research questions as well. Comparisons between patients having benign and malignant lesions and between young and older patients may be particularly important to consider. Additionally, the relation between quality of life and quality of care through the eyes of different patient groups would be a relevant topic for further research.

A weakness of using standardised instruments like CQI questionnaires might be that measured aspects of care for a large part reflect themes relevant for the bulk of patients, and that aspects experienced by only small subgroups of patients remain unresolved. For example, a few focus group participants reported negative experiences with immediate breast conserving treatment. In the questionnaire, however, it is not efficient to measure experiences on this topic, because the number of patients receiving this treatment is relatively small. Therefore, hospitals should use CQI results as a basis to further unravel problems on specific aspects, rather than as the mere instrument to assess quality of breast care.

In addition, the instrument seems less appropriate to measure healthcare outcomes. Although the questionnaire contains some items on treatment outcomes, such as surgery complications, questions could be raised about surveying patients on these relatively objective and complex themes. For example, a question about surgical non-radicality is part of the CQI-BC, but this aspect might be more appropriately measured by hospitals themselves. At any rate, CQI information on breast care should be combined with data from other sources such as medical records in hospital profiling studies.

At present, the CQI-BC is being further developed and adjusted. In this further development, we constantly aim to abbreviate the instrument, rather than to expand it. An important current point of discussion is whether the experience instrument should be divided into two separate questionnaires: one for malignant breast disorder and one for benign breast disorder. In the constructing phase, we chose the option of one instrument on practical considerations. In future data collections using the instrument, however, it might be more efficient to have two separate instruments, and let hospitals and health insurance companies apply the instruments either separately or in combination. An additional benefit is that the questionnaire for benign lesions becomes shorter, and that these patients cannot become worried from terminology concerning breast cancer.

Another important issue is the ability of the instrument to assess quality differences between hospitals (discriminative power). A recent British study found significant differences between hospitals on patient satisfaction with breast care. ${ }^{20}$ It is interesting to know whether a measurement with the new CQ-index instrument on patient experience will 
Damman, O.C., Hendriks, M., Sixma, H.J. Towards more patient centred healthcare: a new Consumer Quality Index instrument to assess patients' experiences with breast care. European Journal of Cancer: 2009, 45(9), 1569-1577

also yield significant differences between hospitals. Considering the European embracement of public consumer information on hospital performance, future research should test the instrument's discriminative power.

\section{CONCLUSION}

The CQI-BC instrument covers the most important aspects of quality of care according to patients. In the near future, hospitals and other users can use CQ-index information about the quality of breast care. Particularly in combination with other quality indicators, the instrument can contribute to a complete picture of breast care quality.

\section{CONFLICT OF INTEREST STATEMENT}

None declared.

\section{ROLE OF THE FUNDING SOURCES}

The supporting organisation ZonMw (The Netherlands Organisation for Health Research and Development) did not have any involvement in the study. Stichting Miletus (a concordance of Dutch health insurance companies) sponsored the data collection, and this organisation contributed to the project meetings, just like the other key stakeholders.

\section{ACKNOWLEDGEMENTS}

We would like to thank all breast cancer patients who participated in the focus groups, and the stakeholders participating in the project 'CQ-index Breast Care' for their contribution to the development of the instrument.

\section{REFERENCES}

1 H.J. Sixma, J.J. Kerssens, C.V. Campen and L. Peters, Quality of care from the patients' perspective: from theoretical concept to a new measuring instrument, Health Expect 1 (1998), pp. 82-95.

2 R. Mannion and H.T. Davies, Reporting healthcare performance: learning from the past, prospects for the future, J Eval Clin Pract 8 (2) (2002), pp. 215-228.

3 C. Darby, C. Crofton and C.M. Clancy, Consumer assessment of health providers and systems (CAHPS): evolving to meet stakeholder needs, Am J Med Qual 21 (2) (2006), pp. 144-147.

4 J.H. Stubbe, T. Gelsema and D.M. Delnoij, The Consumer Quality Index Hip Knee Questionnaire measuring patients' experiences with quality of care after a total hip or knee arthroplasty, BMC Health Serv Res 7 (2007), p. 60.

5 J.H. Stubbe, W. Brouwer and D.M.J. Delnoij, Patients' experiences with quality of hospital care: the Consumer Quality Index Cataract Questionnaire, BMC Ophthalmol 7 (2007), p. 14.

6 J.L. Hargraves, R.D. Hays and P.D. Cleary, Psychometric properties of the Consumer Assessment of Health Plans Study (CAHPS $\left.{ }^{\circledR}\right)$ 2.0 Adult Core Survey, Health Serv Res 38 (6 Pt 1) (2003), pp. 1509-1527.

7 D.C. Cleary and S. Edgman-Levitan, Health care quality: incorporating consumer perspectives, JAMA 278 (19) (1997), pp. 1608-1612.

$8 \mathrm{M}$. Hendriks, O.C. Damman, P. Spreeuwenberg and D. Delnoij, Have the performances of Dutch health plan changed over the years? A comparison with the Consumer Quality Index healthcare and health insurer, Eur J Public Health 17 (Suppl. 2) (2007), pp. 34-35.

9 O.A. Arah, A.H. ten Asbroek and D.M. Delnoij et al., Psychometric properties of the Dutch version of the Hospital level Consumer Assessment of Health Plans Survey instrument, Health Serv Res 41 (2006), pp. 284-301.) 
Damman, O.C., Hendriks, M., Sixma, H.J. Towards more patient centred healthcare: a new Consumer Quality Index instrument to assess patients' experiences with breast care. European )

Journal of Cancer: 2009, 45(9), 1569-1577

10 M. Zuidgeest and H.J. Sixma, De ontwikkeling van een CQI meetinstrument voor de gehandicaptenzorg. (The development of a CQI instrument for care for the handicapped), Kwaliteit Beeld 2 (2007), pp. 10-12.

11 B. Rabinowitz, Psychosocial issues in breast cancer, Obstet Gynecol Clin North Am 29 (1) (2002), pp. 233-247.

12 A.B. Kornblith and J. Ligibel, Psychosocial and sexual functioning of survivors of breast cancer, Semin Oncol 30 (6) (2003), pp. 799-813.

13 F. Mols, A.J. Vingerhoets, J.W. Coebergh and L.V. van de Poll-Franse, Quality of life among long-term breast cancer survivors: a systematic review, Eur J Cancer 41 (17) (2005), pp. 2613-2619.

14 M.T. Knobf, The influence of endocrine effects of adjuvant therapy on quality of life outcomes in younger breast cancer survivors, Oncologist 11 (2) (2006), pp. 96-110.)

15 J.H. Hibbard, J. Stockard and M. Tusler, Hospital performance reports: impact on quality, market share, and reputation, Health Aff (Millwood) 24 (4) (2005), pp. 1150-1160.

16 H.J. Sixma, D.M. Delnoij and J.H. Stubbe et al., Handboek CQI meetinstrumenten. Een handleiding voor de ontwikkeling en het gebruik van Consumer Quality Index (CQI) vragenlijsten. (Manual CQI instruments. An instruction for the development and use of Consumer Quality Index (CQI) questionnaires), Centrum Klantervaring Zorg, Utrecht (2007).

17 D.L. Morgan, The focus group kit (1): the focus group guide book, Sage, Thousand Oaks (1998).

18 M. de Kok, R.W. Scholte and H.J. Sixma et al., The patient's perspective of the quality of breast cancer care. The development of an instrument to measure quality of care through focus groups and concept mapping with breast cancer patients, Eur J Cancer 43 (8) (2007), pp. 1257-1264.

19 D.A. Dillman, Mail and internet surveys: the tailored Design Method, Wiley, New York (2000).

20 C. Sherlaw-Johnson, P. Datta and M. McCarthy, Hospital differences in patient satisfaction with care for breast, colorectal, lung and prostate cancers, Eur J Cancer 44 (11) (2008), pp. 1559-1565.

\section{TABLES AND FigURE}

Table 1

\begin{tabular}{|l|l|l|l|}
\hline $\begin{array}{l}\text { Questionnaire } \\
\text { section }\end{array}$ & Item & Type of item & $\begin{array}{c}\text { Importance } \\
\text { questionnaire }\end{array}$ \\
\hline $\begin{array}{l}\text { Breast } \\
\text { examinations }\end{array}$ & Detecting breast disease & General item ${ }^{\mathrm{a}}$ & No \\
\hline & $\begin{array}{l}\text { Promptness of availability of X- } \\
\text { ray results from population } \\
\text { screening }\end{array}$ & Time schedule \\
\hline & $\begin{array}{l}\text { Way of receiving results of X-ray } \\
\text { from population screening }\end{array}$ & General item & Yes \\
\hline & $\begin{array}{l}\text { Promptness of referral from } \\
\text { general practitioner to hospital }\end{array}$ & Time schedule & Yes \\
\hline & $\begin{array}{l}\text { Promptness of hospital } \\
\text { appointment following referral }\end{array}$ & Time schedule & Yes \\
\hline & $\begin{array}{l}\text { Referral to specialised centre } \\
\text { Number of examinations on the } \\
\text { same day }\end{array}$ & General item & Time schedule \\
\hline
\end{tabular}


Damman, O.C., Hendriks, M., Sixma, H.J. Towards more patient centred healthcare: a new Consumer Quality Index instrument to assess patients' experiences with breast care. European )

Journal of Cancer: 2009, 45(9), 1569-1577

\begin{tabular}{|c|c|c|c|}
\hline $\begin{array}{l}\text { Questionnaire } \\
\text { section }\end{array}$ & Item & Type of item & $\begin{array}{l}\text { Importance } \\
\text { questionnaire }\end{array}$ \\
\hline & $\begin{array}{l}\text { Informing about breast cancer in } \\
\text { the family }\end{array}$ & Experience $(1-2)^{\mathrm{c}}$ & Yes \\
\hline & $\begin{array}{l}\text { Rapid availability } \\
\text { mammography/ultrasound results }\end{array}$ & Time schedule & Yes $^{\mathrm{j}}$ \\
\hline & $\begin{array}{l}\text { Rapid availability puncture } \\
\text { results }\end{array}$ & Time schedule & Yes $^{\mathrm{j}}$ \\
\hline & Rapid availability biopsy results & Time schedule & $\mathrm{Yes}^{\mathrm{j}}$ \\
\hline & $\begin{array}{l}\text { Caregivers explain things in a } \\
\text { way that is easy to understand }\end{array}$ & Experience $(1-4)^{\mathrm{d}}$ & Yes $^{\mathrm{j}}$ \\
\hline & $\begin{array}{l}\text { Getting enough information from } \\
\text { caregivers }\end{array}$ & Experience (1-4) & Yes $^{\mathrm{j}}$ \\
\hline & $\begin{array}{l}\text { Opportunity to ask questions to } \\
\text { caregivers }\end{array}$ & Experience (1-4) & Yes $^{\mathrm{j}}$ \\
\hline & $\begin{array}{l}\text { Information sources in the phase } \\
\text { of breast examinations }\end{array}$ & General item & No \\
\hline & Receiving written information & $\begin{array}{l}\text { Skipitem }{ }^{\mathrm{e}}+\text { Experience } \\
(1-2)\end{array}$ & $\mathrm{Yes}^{\mathrm{j}}$ \\
\hline & $\begin{array}{l}\text { Comprehensiveness of written } \\
\text { information }\end{array}$ & Experience (1-4) & Yes $^{\mathrm{j}}$ \\
\hline & Contact with general practitioner & Skipitem & No \\
\hline & $\begin{array}{l}\text { General practitioner listens } \\
\text { carefully }\end{array}$ & Experience (1-4) & Yes $^{\mathrm{j}}$ \\
\hline & $\begin{array}{l}\text { General practitioner spends } \\
\text { enough time with you }\end{array}$ & Experience (1-4) & $\mathrm{Yes}^{\mathrm{j}}$ \\
\hline & $\begin{array}{l}\text { General practitioner takes you } \\
\text { seriously }\end{array}$ & Experience (1-4) & Yes $^{\mathrm{j}}$ \\
\hline & $\begin{array}{l}\text { General practitioner shows } \\
\text { personal attention to you }\end{array}$ & Experience (1-4) & Yes $^{\mathrm{j}}$ \\
\hline & Global rating general practitioner & Global rating $(0-10)^{\mathrm{f}}$ & No \\
\hline & Caregivers listen carefully & Experience (1-4) & Yes $^{\mathrm{j}}$ \\
\hline & $\begin{array}{l}\text { Caregivers spend enough time } \\
\text { with you }\end{array}$ & Experience (1-4) & Yes $^{\mathrm{j}}$ \\
\hline & Caregivers take you seriously & Experience (1-4) & $\mathrm{Yes}^{\mathrm{j}}$ \\
\hline & $\begin{array}{l}\text { Caregivers show personal } \\
\text { attention to you }\end{array}$ & Experience (1-4) & $\mathrm{Yes}^{\mathrm{j}}$ \\
\hline & Global rating breast & Global rating (0-10) & No \\
\hline
\end{tabular}


Damman, O.C., Hendriks, M., Sixma, H.J. Towards more patient centred healthcare: a new Consumer Quality Index instrument to assess patients' experiences with breast care. European ) Journal of Cancer: 2009, 45(9), 1569-1577

\begin{tabular}{|c|c|c|c|}
\hline $\begin{array}{l}\text { Questionnaire } \\
\text { section }\end{array}$ & Item & Type of item & $\begin{array}{l}\text { Importance } \\
\text { questionnaire }\end{array}$ \\
\hline & examinations & & \\
\hline \multirow[t]{19}{*}{$\begin{array}{l}\text { Breast cancer } \\
\text { surgery }\end{array}$} & Having diagnosis breast cancer & Skipitem & No \\
\hline & Having breast surgery & Skipitem & No \\
\hline & Formulating treatment plan & $\begin{array}{l}\text { Experience (1- } \\
\text { 2) + skipitem }\end{array}$ & No \\
\hline & Deciding about treatment & Experience (1-4) & Yes $^{\mathrm{j}}$ \\
\hline & $\begin{array}{l}\text { Taking into account specific } \\
\text { wishes about treatment }\end{array}$ & Experience (1-4) & Yes $^{j}$ \\
\hline & $\begin{array}{l}\text { Discussing the effects of } \\
\text { potential treatments }\end{array}$ & Experience (1-2) & Yes $^{j}$ \\
\hline & Information on second opinion & Experience (1-2) & Yes \\
\hline & $\begin{array}{l}\text { Consult radiotherapist preceding } \\
\text { medical surgery }\end{array}$ & Experience (1-2) & Yes \\
\hline & $\begin{array}{l}\text { Coordination of care by } \\
\text { specialised nurse }\end{array}$ & Experience (1-2) & Yes \\
\hline & $\begin{array}{l}\text { Consult specialised nurse } \\
\text { preceding medical surgery }\end{array}$ & $\begin{array}{l}\text { Experience (1-2)+ } \\
\text { skipitem }\end{array}$ & Yes \\
\hline & $\begin{array}{l}\text { Treatment before medical } \\
\text { surgery }\end{array}$ & Skipitem & No \\
\hline & $\begin{array}{l}\text { Rapid surgery following } \\
\text { diagnosis }\end{array}$ & Time schedule & Yes \\
\hline & $\begin{array}{l}\text { Cosmetic result meets } \\
\text { expectations }\end{array}$ & Opinion $^{g}$ & Yes \\
\hline & $\begin{array}{l}\text { Complications following medical } \\
\text { surgery (bleedings, infections, } \\
\text { wound infections, surgical non- } \\
\text { radicality) }\end{array}$ & Outcome item ${ }^{\mathrm{h}}$ & Yes \\
\hline & Second surgery required & Outcome item & Yes \\
\hline & $\begin{array}{l}\text { Information on sentinel node } \\
\text { biopsy }\end{array}$ & Experience (1-2) & Yes \\
\hline & $\begin{array}{l}\text { Consult on medical surgery } \\
\text { effects }\end{array}$ & Experience (1-2) & Yes \\
\hline & Information on the use of drains & Experience (1-2) & Yes \\
\hline & $\begin{array}{l}\text { Time before drains were } \\
\text { removed }\end{array}$ & Time schedule & Yes \\
\hline
\end{tabular}


Damman, O.C., Hendriks, M., Sixma, H.J. Towards more patient centred healthcare: a new Consumer Quality Index instrument to assess patients' experiences with breast care. European )

Journal of Cancer: 2009, 45(9), 1569-1577

\begin{tabular}{|c|c|c|c|}
\hline $\begin{array}{l}\text { Questionnaire } \\
\text { section }\end{array}$ & Item & Type of item & $\begin{array}{c}\text { Importance } \\
\text { questionnaire }\end{array}$ \\
\hline & Having mastectomy & Skipitem & No \\
\hline & $\begin{array}{l}\text { Information on breast conserving } \\
\text { treatment }\end{array}$ & Experience (1-2) & Yes \\
\hline & $\begin{array}{l}\text { Information on external breast } \\
\text { prostheses }\end{array}$ & Experience (1-2) & Yes \\
\hline & $\begin{array}{l}\text { Having breast conserving } \\
\text { treatment }\end{array}$ & Skipitem & No \\
\hline & $\begin{array}{l}\text { Promptness of breast conserving } \\
\text { treatment }\end{array}$ & Time schedule & Yes \\
\hline & $\begin{array}{l}\text { Satisfaction cosmetic result } \\
\text { breast conserving treatment }\end{array}$ & Opinion & Yes \\
\hline & $\begin{array}{l}\text { Caregivers explain things in a } \\
\text { way that is easy to understand in } \\
\text { the phase of medical surgery }\end{array}$ & Experience (1-4) & Yes $^{j}$ \\
\hline & $\begin{array}{l}\text { Getting enough information from } \\
\text { caregivers in the phase of medical } \\
\text { surgery }\end{array}$ & Experience (1-4) & Yes $^{j}$ \\
\hline & $\begin{array}{l}\text { Opportunity to ask questions to } \\
\text { caregivers in the phase of medical } \\
\text { surgery }\end{array}$ & Experience (1-4) & Yes $^{j}$ \\
\hline & $\begin{array}{l}\text { Information sources in the phase } \\
\text { of medical surgery }\end{array}$ & General item & No \\
\hline & Receiving written information & $\begin{array}{l}\text { Skipitem + Experience } \\
(1-2)\end{array}$ & Yes $^{j}$ \\
\hline & $\begin{array}{l}\text { Comprehensiveness of written } \\
\text { information }\end{array}$ & Experience (1-4) & Yes $^{j}$ \\
\hline & Contact with surgeon & Skipitem & No \\
\hline & Surgeon listens carefully & Experience (1-4) & Yes $^{j}$ \\
\hline & $\begin{array}{l}\text { Surgeon spends enough time } \\
\text { with you }\end{array}$ & Experience (1-4) & Yes $^{j}$ \\
\hline & Surgeon takes you seriously & Experience (1-4) & Yes $^{j}$ \\
\hline & $\begin{array}{l}\text { Surgeon shows personal attention } \\
\text { to you }\end{array}$ & Experience (1-4) & Yes $^{j}$ \\
\hline & Global rating surgeon & Global rating(0-10) & No \\
\hline & Contact with specialised nurse & Skipitem & No \\
\hline & $\begin{array}{l}\text { Specialised nurse listens } \\
\text { carefully }\end{array}$ & Experience (1-4) & Yes $^{j}$ \\
\hline
\end{tabular}


Damman, O.C., Hendriks, M., Sixma, H.J. Towards more patient centred healthcare: a new Consumer Quality Index instrument to assess patients' experiences with breast care. European )

Journal of Cancer: 2009, 45(9), 1569-1577

\begin{tabular}{|c|c|c|c|}
\hline \multirow[t]{5}{*}{$\begin{array}{l}\text { Questionnaire } \\
\text { section }\end{array}$} & Item & Type of item & $\begin{array}{c}\text { Importance } \\
\text { questionnaire }\end{array}$ \\
\hline & $\begin{array}{l}\text { Specialised nurse spends enough } \\
\text { time with you }\end{array}$ & Experience (1-4) & Yes $^{j}$ \\
\hline & $\begin{array}{l}\text { Specialised nurse takes you } \\
\text { seriously }\end{array}$ & Experience (1-4) & Yes $^{j}$ \\
\hline & $\begin{array}{l}\text { Specialised nurse shows personal } \\
\text { attention to you }\end{array}$ & Experience (1-4) & Yes $^{j}$ \\
\hline & Global rating specialised nurse & Global rating(0-10) & No \\
\hline \multirow[t]{18}{*}{ Other treatment } & Having other treatment & Skipitem & No \\
\hline & Deciding about treatment & Experience (1-4) & Yes $^{j}$ \\
\hline & $\begin{array}{l}\text { Taking into account specific } \\
\text { wishes about treatment }\end{array}$ & Experience (1-4) & Yes $^{j}$ \\
\hline & Having radiotherapy & Skipitem & No \\
\hline & Promptness of radiotherapy & Time schedule & Yes $^{j}$ \\
\hline & $\begin{array}{l}\text { Information on side effects of } \\
\text { radiotherapy }\end{array}$ & Experience (1-2) & Yes $^{\mathrm{j}}$ \\
\hline & $\begin{array}{l}\text { Caregivers explain things in a } \\
\text { way that is easy to understand }\end{array}$ & Experience (1-4) & $\mathrm{Yes}^{\mathrm{j}}$ \\
\hline & $\begin{array}{l}\text { Getting enough information from } \\
\text { caregivers }\end{array}$ & Experience (1-4) & Yes $^{j}$ \\
\hline & $\begin{array}{l}\text { Opportunity to ask questions to } \\
\text { caregivers }\end{array}$ & Experience (1-4) & Yes $^{j}$ \\
\hline & $\begin{array}{l}\text { Information sources in the phase } \\
\text { of radiotherapy }\end{array}$ & General item & No \\
\hline & Receiving written information & $\begin{array}{l}\text { Skipitem + Experience } \\
(1-2)\end{array}$ & Yes $^{j}$ \\
\hline & $\begin{array}{l}\text { Comprehensiveness of written } \\
\text { information }\end{array}$ & Experience (1-4) & Yes $^{j}$ \\
\hline & Caregivers listen carefully & Experience (1-4) & Yes $^{j}$ \\
\hline & $\begin{array}{l}\text { Caregivers spend enough time } \\
\text { with you }\end{array}$ & Experience (1-4) & Yes $^{j}$ \\
\hline & Caregivers take you seriously & Experience (1-4) & Yes $^{j}$ \\
\hline & $\begin{array}{l}\text { Caregivers show personal } \\
\text { attention to you }\end{array}$ & Experience (1-4) & Yes $^{j}$ \\
\hline & Global rating radiotherapy & Global rating $(0-10)$ & No \\
\hline & Having chemotherapy & Skipitem & No \\
\hline
\end{tabular}


Damman, O.C., Hendriks, M., Sixma, H.J. Towards more patient centred healthcare: a new Consumer Quality Index instrument to assess patients' experiences with breast care. European ) Journal of Cancer: 2009, 45(9), 1569-1577

\begin{tabular}{|c|c|c|c|}
\hline $\begin{array}{l}\text { Questionnaire } \\
\text { section }\end{array}$ & Item & Type of item & $\begin{array}{l}\text { Importance } \\
\text { questionnaire }\end{array}$ \\
\hline & Promptness of chemotherapy & Time schedule & Yes $^{\mathrm{j}}$ \\
\hline & $\begin{array}{l}\text { Information on side effects of } \\
\text { chemotherapy }\end{array}$ & Experience (1-2) & $\mathrm{Yes}^{\mathrm{j}}$ \\
\hline & $\begin{array}{l}\text { Caregivers explain things in a } \\
\text { way that is easy to understand }\end{array}$ & Experience (1-4) & $\mathrm{Yes}^{\mathrm{j}}$ \\
\hline & $\begin{array}{l}\text { Getting enough information from } \\
\text { caregivers }\end{array}$ & Experience (1-4) & $\mathrm{Yes}^{\mathrm{j}}$ \\
\hline & $\begin{array}{l}\text { Opportunity to ask questions to } \\
\text { caregivers }\end{array}$ & Experience (1-4) & Yes $^{\mathrm{j}}$ \\
\hline & $\begin{array}{l}\text { Information sources in the phase } \\
\text { of chemotherapy }\end{array}$ & General item & No \\
\hline & Receiving written information & $\begin{array}{l}\text { Skipitem + Experience } \\
(1-2)\end{array}$ & Yes $^{\mathrm{j}}$ \\
\hline & $\begin{array}{l}\text { Comprehensiveness of written } \\
\text { information }\end{array}$ & Experience (1-4) & $\mathrm{Yes}^{\mathrm{j}}$ \\
\hline & Caregivers listen carefully & Experience (1-4) & Yes $^{\mathrm{j}}$ \\
\hline & $\begin{array}{l}\text { Caregivers spend enough time } \\
\text { with you }\end{array}$ & Experience (1-4) & Yes $^{\mathrm{j}}$ \\
\hline & Caregivers take you seriously & Experience (1-4) & Yes $^{\mathrm{j}}$ \\
\hline & $\begin{array}{l}\text { Caregivers show personal } \\
\text { attention to you }\end{array}$ & Experience (1-4) & Yes $^{\mathrm{j}}$ \\
\hline & Global rating chemotherapy & Global rating (0-10) & No \\
\hline & Having immune therapy & Skipitem & No \\
\hline & Global rating immune therapy & Global rating(0-10) & No \\
\hline & Having hormone therapy & Skipitem & No \\
\hline & Global rating hormone therapy & Global rating (0-10) & No \\
\hline \multirow[t]{5}{*}{ After treatment } & $\begin{array}{l}\text { Preparing for the period after } \\
\text { treatment }\end{array}$ & Experience (1-4) & Yes \\
\hline & $\begin{array}{l}\text { Information on psychosocial } \\
\text { healthcare }\end{array}$ & Experience (1-2) & Yes \\
\hline & $\begin{array}{l}\text { Assistance concerning referral to } \\
\text { psychosocial healthcare }\end{array}$ & $\begin{array}{l}\text { Experience }(1- \\
\text { 2) + skipitem }\end{array}$ & Yes \\
\hline & $\begin{array}{l}\text { Promptness of psychosocial } \\
\text { healthcare }\end{array}$ & Time schedule & Yes \\
\hline & Information on physiotherapy & Experience (1-2) & Yes \\
\hline
\end{tabular}


Damman, O.C., Hendriks, M., Sixma, H.J. Towards more patient centred healthcare: a new Consumer Quality Index instrument to assess patients' experiences with breast care. European )

Journal of Cancer: 2009, 45(9), 1569-1577

\begin{tabular}{|c|c|c|c|}
\hline $\begin{array}{l}\text { Questionnaire } \\
\text { section }\end{array}$ & Item & Type of item & $\begin{array}{l}\text { Importance } \\
\text { questionnaire }\end{array}$ \\
\hline & $\begin{array}{l}\text { Assistance concerning referral to } \\
\text { physiotherapy }\end{array}$ & $\begin{array}{l}\text { Experience }(1- \\
\text { 2) + skipitem }\end{array}$ & Yes \\
\hline & Promptness of physiotherapy & Time schedule & Yes \\
\hline & Information on rehabilitation & Experience (1-2) & Yes \\
\hline & $\begin{array}{l}\text { Assistance concerning referral to } \\
\text { rehabilitation }\end{array}$ & $\begin{array}{l}\text { Experience (1- } \\
\text { 2) + skipitem }\end{array}$ & Yes \\
\hline & Promptness of rehabilitation & Time schedule & Yes \\
\hline & $\begin{array}{l}\text { Information on return to daily } \\
\text { activities }\end{array}$ & Experience (1-2) & Yes \\
\hline & $\begin{array}{l}\text { Information on patient } \\
\text { organisations }\end{array}$ & Experience (1-2) & Yes \\
\hline \multirow[t]{7}{*}{$\begin{array}{l}\text { Cooperation } \\
\text { and continuity }\end{array}$} & $\begin{array}{l}\text { Coordination of treatments by } \\
\text { different caregivers }\end{array}$ & Experience (1-4) & Yes \\
\hline & $\begin{array}{l}\text { Coordination of advises by } \\
\text { different caregivers }\end{array}$ & Experience (1-4) & Yes \\
\hline & $\begin{array}{l}\text { Arrangements between different } \\
\text { caregivers }\end{array}$ & Experience (1-4) & Yes \\
\hline & $\begin{array}{l}\text { Contradictory information from } \\
\text { different caregivers }\end{array}$ & Experience (1-4) & Yes \\
\hline & $\begin{array}{l}\text { Knowledge about appointments } \\
\text { with other caregivers }\end{array}$ & Experience (1-4) & Yes \\
\hline & $\begin{array}{l}\text { Having to tell the same story } \\
\text { again to caregivers }\end{array}$ & Experience (1-4) & Yes \\
\hline & $\begin{array}{l}\text { Cooperation hospital caregivers } \\
\text { and general practitioner }\end{array}$ & Experience (1-4) & Yes \\
\hline \multirow[t]{7}{*}{ Accessibility } & Telephonic access of hospital & Experience $(1-3)^{\mathrm{i}}$ & Yes \\
\hline & $\begin{array}{l}\text { Getting the information needed } \\
\text { by phone }\end{array}$ & Experience (1-4) & $\mathrm{Yes}^{\mathrm{j}}$ \\
\hline & Email access of hospital & Experience (1-3) & Yes \\
\hline & $\begin{array}{l}\text { Getting the information needed } \\
\text { by email }\end{array}$ & Experience (1-4) & $\mathrm{Yes}^{\mathrm{j}}$ \\
\hline & $\begin{array}{l}\text { Central point for problems or } \\
\text { questions }\end{array}$ & Experience (1-2) & Yes \\
\hline & Treatment according to planning & Experience (1-2) & Yes \\
\hline & $\begin{array}{l}\text { Seen within } 15 \text { minutes of } \\
\text { appointment time }\end{array}$ & Experience (1-4) & Yes \\
\hline
\end{tabular}


Damman, O.C., Hendriks, M., Sixma, H.J. Towards more patient centred healthcare: a new Consumer Quality Index instrument to assess patients' experiences with breast care. European ) Journal of Cancer: 2009, 45(9), 1569-1577

\begin{tabular}{|c|c|c|c|}
\hline $\begin{array}{l}\text { Questionnaire } \\
\text { section }\end{array}$ & Item & Type of item & $\begin{array}{l}\text { Importance } \\
\text { questionnaire }\end{array}$ \\
\hline & $\begin{array}{l}\text { Coming back to hospital because } \\
\text { of concerns }\end{array}$ & Skipitem & No \\
\hline & $\begin{array}{l}\text { Waiting time for coming back to } \\
\text { hospital }\end{array}$ & Experience (1-3) & Yes \\
\hline & $\begin{array}{l}\text { Caregivers' willingness to talk } \\
\text { about errors or incidents }\end{array}$ & Experience (1-4) & Yes \\
\hline & Privacy in the hospital & Experience (1-4) & Yes \\
\hline \multirow[t]{2}{*}{ Expertise } & Professional skills caregivers & Experience (1-4) & Yes \\
\hline & Trust in caregivers & Experience (1-4) & Yes \\
\hline \multirow[t]{3}{*}{$\begin{array}{l}\text { Global rating } \\
\text { hospital }\end{array}$} & Global rating hospital & Global rating (0-10) & No \\
\hline & $\begin{array}{l}\text { Recommending hospital to other } \\
\text { patients }\end{array}$ & Opinion (1-4) & No \\
\hline & $\begin{array}{l}\text { If one thing could be changed in } \\
\text { hospital breast care, what would } \\
\text { that be }\end{array}$ & Opinion (open) & No \\
\hline
\end{tabular}

${ }^{\mathrm{a}}$ General items are items that do not measure specific patient experiences, but more general aspects related to the content of the clinical pathway.

${ }^{b}$ Time schedule items are items on patients' reports of promptness of healthcare and of the availability of results.

${ }^{\mathrm{c}}$ Experience items (1-2) are items on whether or not (yes, no) quality criteria are met according to patient.

${ }^{\mathrm{d}}$ Experience items (1-4) are items on the frequency (never, sometimes, usually and always) with which quality criteria are met according to patients.

e Skipitems are items that refer to another question when follow-up items are not applicable.

${ }^{\mathrm{f}}$ Global ratings are items on a global evaluation of healthcare and healthcare providers on a scale from zero to ten.

${ }^{\mathrm{g}}$ Opinion items are items on patients' evaluation of healthcare outcomes.

${ }^{\mathrm{h}}$ Outcome items are items on healthcare outcomes

${ }^{\text {i }}$ Experience items (1-3) are items on how much of a problem (a big problem, a small problem and no problem) certain aspects of care, related to accessibility, are to patients. ${ }^{\mathrm{j}}$ An importance item was formulated, but this item concerned more than one experience items. For example, one item on rapid availability of research results (in stead of items on all specific examinations separately) and one item on conduct of healthcare professionals (in stead of items on all specialised professionals separately). 
Damman, O.C., Hendriks, M., Sixma, H.J. Towards more patient centred healthcare: a new Consumer Quality Index instrument to assess patients' experiences with breast care. European

Journal of Cancer: 2009, 45(9), 1569-1577

Table 2. Scales with their reliability.

\begin{tabular}{|c|c|c|c|}
\hline Scale & $\begin{array}{l}\text { Number of } \\
\text { items }\end{array}$ & $\alpha$ & Example of item \\
\hline $\begin{array}{l}\text { Conduct of professionals } \\
\text { during breast examination }\end{array}$ & 7 & 0.91 & $\begin{array}{l}\text { How often did caregivers listen carefully to } \\
\text { you? }\end{array}$ \\
\hline $\begin{array}{l}\text { Conduct of general } \\
\text { practitioner }\end{array}$ & 4 & 0.89 & How often did your GP take you seriously? \\
\hline Conduct of nurses & 5 & 0.88 & $\begin{array}{l}\text { How often did nurses show personal } \\
\text { attention to you? }\end{array}$ \\
\hline Conduct of surgeon & 4 & 0.91 & $\begin{array}{l}\text { How often did the surgeon spend enough } \\
\text { time with you? }\end{array}$ \\
\hline $\begin{array}{l}\text { Autonomy regarding } \\
\text { treatment }\end{array}$ & 4 & 0.84 & $\begin{array}{l}\text { How often did you get the chance to decide } \\
\text { about your treatment? }\end{array}$ \\
\hline $\begin{array}{l}\text { Autonomy regarding } \\
\text { follow-up treatment }\end{array}$ & 2 & 0.93 & $\begin{array}{l}\text { How often were your specific wishes about } \\
\text { follow-up treatment taken into account? }\end{array}$ \\
\hline $\begin{array}{l}\text { Conduct of professionals } \\
\text { during radiotherapy }\end{array}$ & 5 & 0.89 & $\begin{array}{l}\text { How often did you get the opportunity to ask } \\
\text { questions about radiotherapy? }\end{array}$ \\
\hline $\begin{array}{l}\text { Information on } \\
\text { radiotherapy }\end{array}$ & 2 & 0.89 & $\begin{array}{l}\text { How often did you get enough information } \\
\text { about radiotherapy? }\end{array}$ \\
\hline $\begin{array}{l}\text { Conduct of professionals } \\
\text { during chemotherapy }\end{array}$ & 4 & 0.90 & $\begin{array}{l}\text { How often did caregivers listen carefully to } \\
\text { you? }\end{array}$ \\
\hline $\begin{array}{l}\text { Information on } \\
\text { chemotherapy }\end{array}$ & 4 & 0.85 & $\begin{array}{l}\text { How often did caregivers explain things } \\
\text { about chemotherapy in a way that was easy to } \\
\text { understand? }\end{array}$ \\
\hline Cooperation & 5 & 0.88 & $\begin{array}{l}\text { How often did caregivers make good } \\
\text { arrangements with each other? }\end{array}$ \\
\hline Accessibility of care & 4 & 0.68 & $\begin{array}{l}\text { How often did you see the doctor within } \\
15 \text { min of your appointment time? }\end{array}$ \\
\hline $\begin{array}{l}\text { Continuity psychosocial } \\
\text { care }\end{array}$ & 3 & 0.83 & $\begin{array}{l}\text { Were you informed about the options of } \\
\text { psychosocial care? }\end{array}$ \\
\hline Continuity physiotherapy & 3 & 0.82 & $\begin{array}{l}\text { Were you assisted concerning a referral to } \\
\text { physiotherapy? }\end{array}$ \\
\hline Continuity rehabilitation & 3 & 0.80 & $\begin{array}{l}\text { Did you have as rapid access to a } \\
\text { rehabilitation program as you wanted? }\end{array}$ \\
\hline
\end{tabular}

$\alpha$ Cronbach's alpha for internal consistency.

Cronbach's alpha of 0.68 is moderately reliable. This scale was accepted at present, yet the question is whether we should report on this aspect in the future. In a future test, this scale should again be investigated. 
Damman, O.C., Hendriks, M., Sixma, H.J. Towards more patient centred healthcare: a new Consumer Quality Index instrument to assess patients' experiences with breast care. European ) Journal of Cancer: 2009, 45(9), 1569-1577

Table 3. Top ten for quality improvement scores with corresponding importance scores and experience scores.

\begin{tabular}{|c|c|c|c|c|c|}
\hline $\begin{array}{l}\text { Quality } \\
\text { aspect }\end{array}$ & $\begin{array}{l}\text { Importance } \\
\text { score }\end{array}$ & $\begin{array}{l}\text { Experience } \\
\text { score } \\
\text { (overall) }\end{array}$ & $\begin{array}{l}\text { Experience } \\
\text { score } \\
\text { (benign) }\end{array}$ & $\begin{array}{c}\text { Experience } \\
\text { score } \\
\text { (malignant) }\end{array}$ & $\begin{array}{l}\text { Improvement } \\
\text { score }\end{array}$ \\
\hline $\begin{array}{l}1 . \\
\text { Information } \\
\text { on second } \\
\text { opinion }\end{array}$ & 3.03 & 0.85 & - & 0.85 & 2.58 \\
\hline $\begin{array}{l}\text { 2. Consult } \\
\text { radiotherapist } \\
\text { preceding } \\
\text { medical } \\
\text { surgery }\end{array}$ & 3.22 & 0.61 & - & 0.61 & 1.96 \\
\hline $\begin{array}{l}3 . \\
\text { Assistance } \\
\text { concerning } \\
\text { referral to } \\
\text { rehabilitation }\end{array}$ & 2.98 & 0.62 & - & 0.62 & 1.85 \\
\hline $\begin{array}{l}4 . \\
\text { Information } \\
\text { on breast } \\
\text { conserving } \\
\text { treatment }\end{array}$ & 3.13 & 0.59 & - & 0.59 & 1.83 \\
\hline $\begin{array}{l}\text { 5. Rapid } \\
\text { availability } \\
\text { biopsy } \\
\text { results }\end{array}$ & 3.78 & 0.48 & 0.54 & 0.47 & 1.83 \\
\hline $\begin{array}{l}\text { 6. Rapid } \\
\text { appointment } \\
\text { in the } \\
\text { hospital } \\
\text { following } \\
\text { referral }\end{array}$ & 3.85 & 0.47 & 0.54 & 0.42 & 1.80 \\
\hline $\begin{array}{l}7 . \\
\text { Information } \\
\text { on } \\
\text { rehabilitation }\end{array}$ & 3.03 & 0.59 & - & 0.59 & 1.78 \\
\hline $\begin{array}{l}8 . \\
\text { Assistance } \\
\text { concerning } \\
\text { referral to } \\
\text { psychosocial } \\
\text { care }\end{array}$ & 2.98 & 0.54 & - & 0.54 & 1.60 \\
\hline $\begin{array}{l}9 . \\
\text { Discussing } \\
\text { the effects of }\end{array}$ & 3.23 & 0.48 & - & 0.48 & 1.56 \\
\hline
\end{tabular}


Damman, O.C., Hendriks, M., Sixma, H.J. Towards more patient centred healthcare: a new Consumer Quality Index instrument to assess patients' experiences with breast care. European Journal of Cancer: 2009, 45(9), 1569-1577

\begin{tabular}{|l|l|l|l|l|l|}
\hline $\begin{array}{c}\text { Quality } \\
\text { aspect }\end{array}$ & $\begin{array}{c}\text { Importance } \\
\text { score }\end{array}$ & $\begin{array}{c}\text { Experience } \\
\text { score } \\
\text { (overall) }\end{array}$ & $\begin{array}{c}\text { Experience } \\
\text { score } \\
\text { (benign) }\end{array}$ & $\begin{array}{c}\text { Experience } \\
\text { score }\end{array}$ & $\begin{array}{c}\text { Improvement } \\
\text { score }\end{array}$ \\
\hline $\begin{array}{l}\text { potential } \\
\text { treatments }\end{array}$ & & & & & \\
\hline $\begin{array}{l}10 . \\
\text { Receiving } \\
\text { written } \\
\text { information } \\
\text { in the phase } \\
\text { of breast } \\
\text { examinations }\end{array}$ & 3.09 & 0.47 & 0.69 & 0.33 & 1.44 \\
\hline
\end{tabular}

Experience scores are presented as proportion negative experience across all patients, across patients with malignant breast disease and across patients with benign breast disease (if applicable). Negative experiences are 'never/sometimes', 'no', or 'a big problem/a small problem' for the different experience items. Negative experiences of time schedule items (numbers 5 and 6 in the top ten) are 'longer than 6 days'.

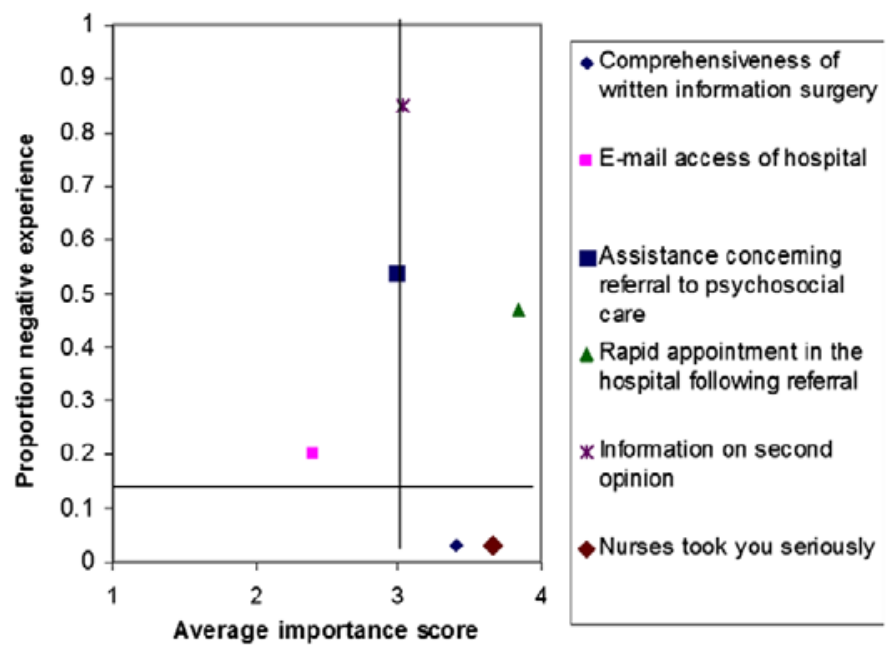

Fig. 1 - Example of quality information for healthcare providers: quadrant figure presenting quality improvement potential: Rule of thumb for importance score: all aspects with an importance score of 3.00 and higher are considered important; Rule of thumb for experience score: all aspects with proportion negative experiences of 0.15 or higher are considered negative experiences. Aspects in the upper right quadrant are aspects that need improvement with priority (action). Aspects in the upper left quadrant are aspects that need improvement without priority (no action). Aspects in the lower right quadrant are plus points (keep up the work). Aspects in the lower left quadrant are relatively unimportant aspects. 